\title{
ÓPERA DE MULHER: PROJETO DE ENCENAÇÃO E INTERPRETAÇÃO MUSICAL ${ }^{1}$
}

\author{
VIANA, Isabel ${ }^{2}$ \\ OLIVEIRA, José Luís de ${ }^{3}$
}

RESUMO: Na interpretação de uma obra musical cantada, em particular de uma ópera, o cantor-ator tem um papel determinante na transmissão não só dos componentes informativos, em nível do texto musical e literário, mas também dos estados emocionais das personagens, através de indicadores ou marcadores não verbais. Neste artigo apresentamos uma proposta de encenação e os métodos que usamos para fundamentar teoricamente o projeto. Trata-se da interpretação de dez personagens femininas soprano de óperas italianas do século XIX, composto por duas árias de cada um dos cinco compositores italianos escolhidos. O espetáculo tem a duração de cerca de 45 minutos e tivemos particular atenção aos estados emocionais de cada uma das personagens, para a interpretação das respetivas árias, bem como a cenografia e os adereços. Com este projeto, concluímos que, ainda que vocal e tecnicamente possa ser bem executada, não é possível realizar uma correta interpretação de uma ária sob o ponto de vista dramático sem conhecer previamente a personagem, a sua personalidade e, especialmente, os estados emocionais presentes em cada um dos momentos.

PALAVRAS-CHAVE: ópera; teatro; séc. XIX; soprano; construção da personagem; estados emocionais.

ABSTRACT: In the performance of a sung musical piece, in particular, an opera, the singer-actor plays a decisive role in the transmission, not only of the informative components of the musical and literary text but also of the emotional states of the characters, through non-verbal indicators or markers. In this article we present a proposal of staging project and the techniques we use to support the project theoretically. This is the interpretation of ten female soprano characters from 19th century Italian operas,

\footnotetext{
${ }^{1}$ Uma versão preliminar deste projeto artístico foi apresentada na dissertação de mestrado da autora (Viana 2012) e levado a cabo na performance da defesa da dissertação. Foi ainda apresentado posteriormente em outros eventos, com ligeiras adaptações. Gostaríamos de agradecer as preciosas contribuições dos dois avaliadores anônimos (blind peer reviewers) cujas análises críticas e recomendações procuramos inserir nesta última versão.

${ }^{2}$ Doutoranda no 3. ${ }^{\circ}$ ciclo de estudos de Música e Musicologia, especialização em Interpretação, da Universidade de Évora (Portugal), e Mestrado em Música, especialização em Performance, pela Universidade de Aveiro (Portugal). Assistente Convidada na Universidade de Trás-os-Montes e Alto Douro, Vila Real (Portugal). E-mail: belviana@utad.pt

3 Doutor em Artes Cénicas pela Universidade de Vigo (Espanha). Professor Auxiliar Convidado na Universidade Trás-os- Montes e Alto Douro (Portugal). E-mail: jloliveira@utad.pt
} 
composed of two arias by five Italian composers. The show lasts approximately 45 minutes, and, for the arias' performance, we paid careful attention to the emotional states of each of the characters, as well as the scenography and the props. With this project, we concluded that, although vocal and technical can be well-executed, it is not possible to perform a correct interpretation of an aria from a dramatic point of view without previously knowing the character, its personality and, especially, the emotional states present in each one of the moments.

KEYWORDS: opera; theatre; 19th century; soprano; building a character; emotional states

\section{INTRODUÇÃO}

$\mathrm{Na}$ interpretação de uma obra musical cantada, em particular de uma ópera, o cantor-ator tem um papel determinante na transmissão não só dos componentes informativos, em nível do texto musical e literário, mas também dos estados emocionais das personagens, através de indicadores ou marcadores não verbais. Neste sentido, este projeto teve como foco o trabalho do ator, o aspecto emocional e não verbal de dez personagens femininas, de dez óperas italianas do Séc. XIX. Com efeito, este trabalho analisa a construção da personagem, aspecto essencial em teatro, mas também na ópera.

No que respeita à encenação, tentamos encontrar um fio condutor que pudesse interligar essas dez personagens, estudando, para isso, as afinidades que pareciam existir entre as suas personalidades e que, no seu conjunto, pudessem contar uma "nova" história e conciliar todo o espetáculo. Com efeito, na ordem de entrada das personagens, tivemos em consideração não só a progressão temática entre as cinco inidades, termo criado a partir da abreviatura de feminidade (com eliminação do radical da palavra), por analogia com o substantivo "unidade", alternandoas entre si, de forma a não tornar o espetáculo demasiado homogêneo (e eventualmente monótono), mas também que as diferenças entre os estados emocionais das personagens fossem claramente percebidas ou detectadas pelo público. Em relação aos adereços, entendemos que os que selecionamos enriqueceram essas personagens e a interpretação das respetivas árias. Os elementos cenográficos foram escolhidos com base nas cinco inidades que estabeleceram o elo entre todas as árias e serviram ao todo da encenação.

\section{Projeto de interpretação musical: ÓPERA ${ }^{4}$ DE MULHER}

\footnotetext{
${ }^{4}$ No sentido de "obra".

Jangada | nr. 14, jul/dez, 2019 | ISSN 2317-4722
} 
A força motriz deste projeto de interpretação foi a ópera na sua gênese. Patrice Pavis refere que,

(...) usando de todos os recursos do teatro, com, além do mais, o prestígio da voz e da música, a ópera representa o teatro por excelência, e este se compraz em ressaltar a convenção e a teatralidade daquela. Arte naturalmente excessiva, baseada em feitos vocais, valorizada pelo pathos da música e pelo prestígio da cena, a ópera «fala» doravante à gente de teatro que lhe traz a sistematicidade de uma encenação e a atuação empenhada, virtuosística e total dos atores. É pelo jogo físico dos atores que não são mais apenas cantores, e sim virtuoses e atletas afetivos, que o teatro veio renovar a encenação de ópera outrora estática, sem imaginação e exclusivamente escrava da música. (2005, p. 268)

No teatro, a interpretação é o elemento fundamental, mas a junção da música e do canto só pode enriquecê-la. $\mathrm{O}$ ator-cantor deverá fazer com que a sua interpretação carregue as emoções das personagens que tiver que vivenciar (THAMM, 2006). Estas emoções devem ser bem visíveis e estar em conformidade com as convenções de representação dos sentimentos de cada cultura. $\mathrm{O}$ ator deve saber gerir as suas emoções e fazer com que estas sejam percebidas pelo público. Deverá saber controlar interiormente as emoções e fazer com que elas sejam (pareçam) verdadeiras para o espectador.

A interpretação da expressividade do ator em palco costuma ser bem evidenciada, por forma a que o espectador, à distância, consiga ter a percepção da emoção naquele momento. Muitas vezes, este código cênico pode parecer exagerado se transposto para outro meio, como, por exemplo, a televisão e o cinema, uma vez que a proximidade entre o ator e o espectador é muito reduzida e, portanto, não há necessidade de "aumentar" essa expressividade.

Num projeto onde se interpretaram árias de personagens femininas, coube-nos tentar perceber as emoções sentidas e vivenciadas por cada personagem naquele momento, para ser possível transportá-las para o palco e, deste modo, para o espectador. Em outra investigação (ver VIANA, 2018b), procuramos demonstrar que o processo de criação de uma personagem é uma imitação da vida real, em que se constrói uma realidade, neste caso, artística e ficcional. Presentemente, os encenadores e, especialmente, os atores seguem várias metodologias no processo de criação/interpretação das personagens, dos quais destacamos, o método de Stanislavski (1863-1938). O diretor do Teatro de Arte de Moscou, e também professor de Arte Dramática, defendeu a respeito do momento de preparação do ator, que este deve reconstruir 
psicológica e meticulosamente a personagem, procurando conhecer o passado, presente e hipotético futuro da personagem, construindo uma história coerente da personagem e estabelecendo o que falta saber a seu respeito e que não está explícito no texto. É, por isso, imperativo fazer-se uso do condicional stanislavskiano: 'Se eu estivesse nessa situação o que faria?'.

No caso para o ator que não sente a emoção ao se expressar dentro desse condicional mágico, ele deve recorrer a meios físicos, como uma lembrança de um fato dele parecido com o da personagem, como também materiais exteriores, como o cristal japonês que produz um lacrimejar quando aplicado nos olhos. Existe também o assumir uma fé cênica, termo utilizado por Stanislavski que significa uma fé absoluta na verdade cênica, ou seja, recorro a uma justificativa interior para cada gesto. Em linhas gerais, deve-se agir sobre o subconsciente, mas permanecendo no plano da consciência, passandose da imaginação à interpretação pela utilização do condicional mágico "se", da observação, da memória da emoção, da fé cênica, da verdade interior e assim por diante. (SIMÕES, 2010, p. 44)

Há uma dualidade artística na interpretação de uma ópera, pois o ator é também cantor e, para além de tentar executar as árias com acerto e todas as técnicas melódicas e vocais, tem também de interpretar os estados emocionais das personagens, de procurar o seu subconsciente e fazer chegar essa verdade ao espectador. Nos dias de hoje é clara a influência de Stanislavski no teatro, mas também na ópera pois, felizmente, os atores-cantores são levados a interpretar variadíssimas emoções, em qualquer posição corporal.

Quando se dá o processo de criação de uma personagem é fulcral que o ator possa estabelecer uma identidade humana para essa mesma personagem, criando uma realidade artística em torno da mesma. $\mathrm{O}$ comportamento do ator deve ser claramente subordinado à personagem que interpreta. Desta forma, o cantor-ator exerce um papel fundamental na transmissão não só das partes informativas das personagens, mas também na interpretação dos seus estados emocionais. Por isso, ao procurarmos as emoções inerentes a cada ária e a cada personagem, para interpreté-las adequadamente, tivemos em linha de conta as sinopses de cada ópera, bem como as partituras com as respetivas melodias, as anotações dos compositores e os próprios textos das árias.

Como falamos de mulheres do período romântico, é natural que a expressão destas Jangada | nr. 14, jul/dez, 2019 | ISSN 2317-4722 
emoções seja feita também, em alguns momentos, de uma forma exacerbada, uma vez que o agigantar dos sentimentos e das emoções é uma das caraterísticas deste período (VIANA, 2018a).

No que concerne a este projeto artístico, a que simplesmente se chamou "ópera (obra) de mulher", interpretaram-se dez árias de dez personagens diferentes dos cinco compositores italianos mais representativos do século XIX (ARAÚJO, 2012). A seleção das árias e das personagens deveu-se aos seguintes critérios: as óperas deveriam ser emblemáticas do compositor; as personagens femininas teriam de ser sopranos, uma vez que a intérprete é soprano; os estados emocionais das personagens deveriam ser diferentes, alguns simples, outros complexos e outros até contraditórios, para que se pudesse obter uma interpretação multifacetada e que cativasse o interesse do espectador; e as árias não deveriam ter sido interpretadas antes pela cantora, para que não existissem condicionamentos de anteriores interpretações e todo este processo fosse também um desafio quer da técnica vocal, quer da interpretação.

Com efeito, propusemo-nos encenar um espetáculo com cerca de 45 minutos e interpretar as seguintes árias, procurando transmitir os estados emocionais das personagens e as suas emoções básicas ou primárias (VIANA, 2014):

1. Lucilla: "Sento talor nell'anima” [Rossini, La scala di seta (1812)];

2. Anna: "Giusto Ciel in tal periglio" [Rossini, Maometto II (1820)];

3. Norma: "Casta Diva” [Bellini, Norma (1831)];

4. Elvira: "Qui la voce sua soave... vien diletto" [Bellini, I Puritani (1835)];

5. Marie: "Ciascun lo dice" [Donizetti, La Figlia del Reggimento (1839)];

6. Rita: "E' lindo e civettin questo caro alberguccio" [Donizetti, Rita (1841)];

7. Gilda: "Tutte le feste al tempio" [Verdi, Rigoletto (1850)];

8. Oscar: "Volta la Terra..." [Verdi, Un Ballo in Maschera (1859)];

9. Anna: "Se come voi piccina io fossi" [Puccini, Le Villi (1884)];

10. Musetta: “Quando men vo" [Puccini, La Bohéme (1895)].

\subsection{Estados emocionais de dez personagens femininas}

\subsubsection{Lucilla (La scala di seta, 1812)}


Ária: "Sento talor nell'anima"

Libretista: Giuseppe Maria Foppa (1760-1845)

Compositor: Gioachino Rossini (1792-1868)

Giulia vive na casa do seu tutor, Dormont, mas casou-se secretamente com o homem que ama, Dorvil. Para se encontrar com ele, tem a ajuda da sua prima Lucilla. Juntas, conseguem que Dorvil suba, todas as noites, por uma escada de seda para o quarto de Giulia e se esconda no armário quando aparece o tutor desta. Tudo se complica quando Dormont apresenta Blansac a Giulia dizendo que é um pretendente que ele escolheu para ela. No entanto, tanto Blansac como Lucilla dão mostras de estarem interessados um no outro. Como Giulia se quer ver livre do pretendente, faz de tudo para que Blansac e Lucilla fiquem juntos. Convencido por Giulia, Blansac demonstra as suas intenções a Lucilla e esta fica radiante.

Falhas de comunicação e mal-entendidos abundam enquanto as personagens saem e entram do armário de Giulia até Dormont descobrir a escada de seda e exigir uma explicação. No final, Dormont abençoa o casamento de Giulia com Dorvil e Blansac casa com Lucilla.

Lucilla é uma jovem de boa família, prestativa e um pouco ingênua. Sonha ter um marido que lhe arrebate o coração. Na ária "Sento talor nell'anima", Lucilla está em êxtase depois de Blansac demonstrar interesse em cortejá-la. Muito feliz, fantasia já com a ideia de um marido a seu lado, demonstrando as seguintes emoções: alegria, esperança, desejo e prazer. São emoções em turbilhão pelo fato de ter recebido uma declaração de interesse amoroso por parte do homem por quem também se sente atraída e com quem já desenha um futuro feliz.

$\mathrm{Na}$ representação desta ária, procuramos utilizar o sorriso como indicador dessa mesma alegria. Os cantos dos lábios estavam ligeiramente puxados para trás e para cima. Os dentes, ocasionalmente visíveis, estando a boca mais ou menos aberta, em dependência do uso da técnica vocal na interpretação musical. Quanto à postura corporal, a personagem estava ereta, com o peito elevado, as costas em tensão, por forma a mostrar o êxtase e o seu contentamento. As dificuldades vocais maiores desta ária foram o andamento bastante rápido, que foi intensificado pela movimentação cênica.

\subsubsection{Anna (Maometto II, 1820)}

Ária: "Giusto Ciel! in tal periglio"

Libretista: Cesare della Valle (1776-1860)

Jangada | nr. 14, jul/dez, 2019 | ISSN 2317-4722

63 |P ág i n a 
Compositor: Gioacchino Rossini (1792-1868)

Maometto II, considerada por Desirée Mays (2012, p. 55) "the best of Rossini's Neopolitan operas", baseia-se na história verídica do sultão turco otomano Mehmet Fatih, Mohammed ou Mehmet II, o conquistador de Constantinopla, em 1453, à qual atribuiu-se o nome de Istambul. Este episódio foi tão importante para a história da civilização europeia que, embora haja divergência entre os historiadores, alguns marcaram com ele o fim da Idade Média e o início da Idade Moderna.

O Império Bizantino ou Império Romano do Oriente, cuja capital era Constantinopla, acaba de cair nas mãos dos turcos e das tropas de Maometto II (sultão Mehmed II). O governador Veneziano, Paolo Erisso, pretende que a sua filha, Anna, se case com Calbo, seu aliado, mas Anna ama um nobre desconhecido que conheceu em Corinto. Maometto chega a Bizâncio e é reconhecido por Anna: ele é o homem que ela ama. Maometto declara-lhe o seu amor e oferece-lhe o trono. Anna sofre um conflito entre o dever perante o pai e a pátria e o amor por Maometto. Em sofrimento, escolhe o dever e casa com Calbo. Maometto jura vingança, mas antes de dar a ordem de ataque a Bizâncio, procura Anna. Ela é confrontada por Maometto e, depois de revelar que realmente, se casou com Calbo apunhala-se a si mesma e morre aos pés de Maometto.

Anna é filha de um governador veneziano pertencente à alta sociedade. É uma jovem apaixonada, mas com um sentido muito acentuado de pátria e de família, uma vez que opta sacrificar-se em prol das mesmas em prejuízo da sua felicidade pessoal. Na ária "Giusto Ciel! in tal periglio", Depois de Maometto saber que Anna se casara com Calbo, ordena ao seu exército que invada a cidade. Anna, recolhe-se numa igreja com outras mulheres e reza para que Deus salve a vida dos seus homens que lutam na batalha. Anna manifesta as seguintes emoções: medo, tristeza, desespero e dor. Anna está dividida, por um lado, pela sua pátria e pelos homens que lutam para a proteger e, por outro, pelo homem que ama e quer que continue a viver.

Na representação da ária "Giusto Ciel! in tal periglio", procuramos mostrar o medo intenso da personagem, através do recolhimento do corpo numa posição de oração, de joelhos, curvada sobre si própria, os braços e o rosto em tensão, com a alteração corporal intensificada por ocasionais tremores. As sobrancelhas estavam elevadas, os olhos semicerrados e o lábio inferior tenso. Esta ária não teve grandes dificuldades técnicas a nível vocal, apenas a realçar o registro médio da tessitura que, para uma soprano dramática, acarreta alguma dificuldade. 


\title{
2.1.3. Norma (Norma, 1831)
}

\author{
Ária: "Casta Diva"
}

Libretista: Felice Romani (1788-1865)

Compositor: Vincenzo Bellini (1801-1835)

A ação de "Norma" se passa na Gália durante a ocupação romana, cerca de 50 anos antes de Cristo. Os druidas esperam a chegada de Norma, a Sacerdotisa, que lhes irá dar o sinal para se revoltarem contra os ocupantes. Norma mantém uma ligação secreta com Pollione, um romano, do qual tem dois filhos. Norma não sabe, mas Pollione ama agora outra mulher, Adalgisa, uma jovem sacerdotisa. Os druidas transmitem a Norma a decisão que tomaram: quando ela der o sinal, eles matarão os ocupantes, começando por Pollione, que fora feito prisioneiro. Norma diz aceitar essa decisão mas, quando fica só, declara seu amor pelo romano. Norma tenta persuadir Pollione para que este deixe Adalgisa, mas este não o faz. Desgostosa, Norma confessa a seu povo a sua traição e a sua culpa, dizendo que deve ser sacrificada. A ópera termina com a morte de Norma e de Pollione, que decide acompanhá-la no sacrifício.

Norma é uma líder sacerdotisa e tem dois filhos, conferindo-lhe uma maturidade considerável. Ciente do seu cargo, é uma mulher carismática e responsável, mas por amor renega a tudo e sacrifica a própria vida. Na ária "Casta Diva", Norma, corajosamente, coloca-se no meio de todos e canta para a Deusa da Lua. Reza-lhe por paz e adia a difícil decisão. Ao mesmo tempo em que reza à Deusa da Lua, Norma canta secretamente pelo seu amor por Pollione, pois só desta forma poderiam continuar juntos. Norma expressa as seguintes emoções: calma, tristeza, ansiedade, medo e esperança. São emoções contraditórias, uma vez que, para o seu povo, Norma tem de demonstrar calma e esperança, dado que é a sua líder e reza à Deusa por paz para todos, mas, no íntimo do seu ser, o que Norma sente é tristeza, medo e ansiedade, pela hipótese de perder Pollione.

$\mathrm{Na}$ interpretação da ária "Casta Diva", procuramos transmitir calma e serenidade da personagem, uma vez que se trata de uma oração diante de todo o povo e tem de esconder as suas verdadeiras emoções. Norma estava de pé, rodando-se sobre si mesma, de forma muito lenta, mantendo sempre a mesma posição (marcação) durante toda a ária. O rosto manteve-se sem qualquer tensão, assim como os lábios. O olhar estava distante, ligeiramente elevado, como se olhasse para a lua..., no entanto, os seus olhos denotavam tristeza, que foi visível por um ligeiro e ocasional elevar das sobrancelhas. Na interpretação vocal desta cavatina, as Jangada | nr. 14, jul/dez, 2019 | ISSN 2317-4722 65 |P ág in a 
dificuldades que se nos aparentaram maiores foram as frases longas, que implicaram uma correta respiração, e o contraste entre longos períodos com uma tessitura média e aguda.

\subsubsection{Elvira (I Puritani, 1835)}

Ária: "Qui la voce sua soave"

Libretista: Carlo Pepoli (1796-1881)

Compositor: Vincenzo Bellini (1801-1835)

A ação decorre em Plymouth, Inglaterra, no século XVII, durante a guerra civil. Elvira, filha do líder Puritano Lord Gualtiero, está apaixonada por Lord Arturo Talbo, leal aos Stuarts. Embora prometida a outro, escolhido por seu pai, este consente que Elvira case-se com Arturo. No dia do casamento, quando Arturo se prepara para deixar o castelo dos Puritanos com sua noiva, encontra Enrichetta, viúva de Charles I, ali aprisionada. Disfarçando-a com roupas de noiva, liberta-a. Elvira, julgando que seu noivo fugiu com outra mulher, enlouquece. Voltando ao castelo, meses depois, para se encontrar com Elvira, Arturo é aprisionado pelos Puritanos, que o condenam à morte. Libertado após um mensageiro anunciar a queda dos Stuarts e a anistia para todos os prisioneiros políticos, Arturo reencontra-se com Elvira, que recobra a razão e unese ao seu amado.

Elvira é filha de um líder pertencente à nobreza, mas é uma mulher frágil e enlouquece por acreditar ter sido abandonada pelo homem que ama. Na ária "Qui la voce sua soave”, Elvira está tresloucada, acreditando que foi deixada pelo homem que ama e que prometera casar-se consigo. A cena de loucura de Elvira, que mergulha com imensa tristeza por o seu amado Arturo a ter abandonado no altar, contrasta com a alegria exagerada e descompensada que revela na brilhante "Vien diletto è in ciel la luna", onde evoca um idílio sob a luz do luar, pedindo a Arturo que volte para ela. É esta dualidade contrastante entre tristeza e alegria que revela o estado de loucura em que Elvira se encontra.

As emoções aqui reveladas são: tristeza, desânimo, desgosto, alegria, desespero. Por um lado, a tristeza, o desânimo e o desgosto e, por outro, a alegria exagerada e o desespero podem invocar duas situações diferentes, mas, neste caso, são provocadas pelo dissabor de acreditar que foi abandonada no altar pelo homem da sua vida.

$\mathrm{Na}$ interpretação desta ária, mostramos a multiplicidade das emoções da personagem, em especial o contraste entre a apatia revelada pela tristeza e o desânimo, com uma postura corporal Jangada | nr. 14, jul/dez, 2019 | ISSN 2317-4722 66 |P á g i n a 
que iniciou com andar lento, corpo lânguido, quase sem vida, passando para uma alegria exagerada, quase histérica, manifestada por uma tensão corporal progressiva, em crescendo, expressa por movimentos bruscos, que terminou em queda, a simbolizar o desespero. $\mathrm{O}$ rosto passou de um estado apático, com os músculos faciais quase em repouso, caídos horizontalmente, para uma tensão muscular acentuada, as maçãs do rosto e as sobrancelhas elevadas, os olhos bem abertos e os lábios trémulos.

As maiores dificuldades que encontramos na interpretação vocal desta ária foram, em primeiro lugar, a conjugação do canto com a interpretação cênica multifacetada. Em segundo lugar, o facto de ser uma ária longa, com diferentes andamentos e frases em coloratura de relativa dificuldade, com notas muito agudas.

\subsubsection{Marie (La Figlia del Reggimento, 1839)}

Ária: "Ciascun lo dice"

Libretista: Jean-François-Alfred Bayard (1796-1853) e Jules-Henri Vernoy de SaintGeorges (1799-1875)

Compositor: Gaetano Donizetti (1797-1848)

Marie é uma jovem que foi criada por soldados desde a morte do seu pai, Capitão Robert, daí chamarem-na Filha do Regimento. Um dia conhece Tonio, um jovem local que lhe salva a vida e os dois se apaixonam. Quando, no Regimento, Sulpice lhe pergunta acerca de um jovem que tem sido visto com ela, Marie explica que é Tonio, um tirolês local que uma vez lhe salvou a vida. As tropas chegam com um prisioneiro que é nada mais nada menos que Tonio. Foi preso pelas tropas quando procurava Marie, mas que as tropas o tomaram por um espião. Ela corre para salvá-lo, explicando às tropas a coragem do jovem quando a salvou. As tropas saúdam Tonio, convidando-o a ficar no Regimento. Enquanto ele brinda com os seus novos amigos, Marie canta a coragem do seu amado e a coragem e nobreza do "seu" Regimento.

Marie descobre que é filha da Marquesa Berkenfield e para lhe fazer a vontade, tenta viver em sua casa, envolta em imensa riqueza. A Marquesa tenta convencê-la a casar-se com um jovem rico, que Marie não ama, mas Tonio e as tropas invadem a cerimónia e quem acaba por casar-se são os apaixonados: Marie e Tonio.

Marie é uma jovem que vive no Regimento militar (décimo primeiro). É engenhosa e corajosa, com modos um pouco masculinos, vestindo roupas militares, como os seus "irmãos" Jangada | nr. 14, jul/dez, 2019 | ISSN 2317-4722 
soldados e sem as maneiras das damas da sociedade. Marie vive feliz no seio do Regimento. Na ária "Ciascun lo dice", Marie expressa as seguintes emoções: alegria, orgulho e amor. Estas emoções são o efeito do orgulho e do amor que sente pelo regimento que a acolheu, onde é tão feliz.

$\mathrm{Na}$ interpretação desta ária, a personagem começou por imitar a marcha dos soldados do regimento, com um andar masculinizado, corpo bem ereto, ombros para trás, cabeça erguida, peito para a frente, joelhos elevados ao nível da anca e braços balanceado para cima e para baixo. No refrão, o corpo balançou de um lado para o outro, como se estivesse a comemorar uma vitória militar numa taberna, com os amigos.

$\mathrm{Na}$ interpretação musical, não encontramos grandes dificuldades, realçando apenas algumas passagens que vão de um registro grave para um agudo muito rapidamente e exigiram uma concentração na manutenção da colocação da voz.

\subsubsection{Rita (Rita, 1841)}

Ária: "È lindo e civettin questo caro alberguccio"

Libretista: Gustave Vaëz (1812-1862)

Compositor: Gaetano Donizetti (1797-1848)

A história da ópera "Rita" começa com Gasparo, marido de Rita, um homem que a maltrata e lhe bate, que faz uma viagem de barco. No entanto, há uma enorme tempestade no mar e o barco naufraga. Ele sobrevive, mas é dado como morto. Ao mesmo tempo, há um incêndio na aldeia e a casa onde vive a sua esposa, Rita, arde totalmente. Chega aos ouvidos de Gasparo, que agora se encontra noutro país, que Rita morreu no incêndio. Assim, cada um pensa que o outro está morto. Gasparo apaixona-se por outra mulher, no Canadá, mas precisa de um atestado de óbito de Rita para poder casar-se novamente. Então, volta a Itália e instala-se numa estalagem. Ao falar com o proprietário, Beppe, Gasparo percebe que o estalajadeiro tem hematomas no seu rosto. Descobre que Rita está a viver lá com o seu novo marido, Beppe, só que, agora, é Rita que bate no marido! Ela reconhece Gasparo que tenta escapar, mas Beppe vê nesta situação uma oportunidade para se libertar das tareias de Rita, uma vez que Gasparo é o marido legítimo. Os dois concordam em fazer um jogo e quem ganhar terá de ficar com Rita. Tanto um como o outro tentam perder, mas no fim Gasparo vence. No entanto, Rita recusa-se a voltar a ser sua esposa. Gasparo induz Beppe a declarar o seu amor por Rita e a sua firme intenção de continuar como Jangada | nr. 14, jul/dez, 2019 | ISSN 2317-4722 
seu marido. Gasparo, tendo conseguido o seu objetivo, despede-se do casal reconciliado e volta para o Canadá.

Rita, que num passado próximo foi vítima de violência doméstica pelo marido, demonstrando ter sido submissa, é agora o oposto, demonstrando ser uma mulher extremamente autoconfiante, segura de si e de personalidade forte, uma vez que é ela que bate no marido e manda em tudo o que pertence a este. Na ária “È lindo e civettin questo caro alberguccio", Rita canta a sua sorte e felicidade por ser dona da sua casa e ter um marido em quem manda e que faz todas as suas vontades. As emoções aqui expressas são a alegria, interesse e prazer.

Na representação desta ária, a personagem veio da plateia, como se estivesse a entrar na estalagem pela primeira vez. O seu corpo denotou autoconfiança e autoridade, esteve, por isso, ereto, peito elevado, cabeça erguida e ombros para trás. No seu rosto, esteve sempre um sorriso, ora de orgulho ora de prazer, mostrando os dentes constantemente, os olhos e as sobrancelhas levantados, bem como as maçãs do rosto. Na interpretação da ária "È lindo e civettin questo caro alberguccio", as dificuldades vocais não foram tecnicamente muito relevantes, mas, como teve muitas marcações cênicas e, tratando-se de uma ária bastante longa, requereu uma atenção constante, para não perder as entradas, o ritmo e a colocação de voz.

\subsubsection{Gilda (Rigoletto, 1850)}

Ária: "Tutte le feste al tempio"

Libretista: Francesco Maria Piave (1810-1876)

Compositor: Giuseppe Verdi (1813-1901)

Este é um drama que narra a história de um personagem homônimo, um bobo, Rigoletto, ao serviço do duque de Mântua. Numa festa, o Duque comenta que se apaixonou por uma misteriosa jovem, durante uma missa, mas, como é um mulherengo, tenta seduzir uma condessa casada. Rigoletto faz comentários sarcásticos sobre os dois. Mais tarde Rigoletto é amaldiçoado pelo pai de uma jovem que foi seduzida pelo Duque. Este diz-lhe que não se deve gozar com os sentimentos de um pai amargurado. Para se vingarem dos gracejos do bobo, os cortesãos pregam-lhe uma partida ao dizerem que vão raptar uma mulher para levar ao Duque e vendam os olhos a Rigoletto enquanto executam o rapto. Na verdade, raptam a jovem por quem o Duque se apaixonou, que, realmente, é a filha de Rigoletto, Gilda. Quando percebe que participou do rapto da própria filha, Rigoletto corre para casa do Duque, reencontra Gilda e revela a todos que 
é seu pai. Gilda, que foi seduzida pelo Duque, confessa ao pai a sua paixão por este. Atemorizado pela maldição que lhe foi lançada, Rigoletto ordena a Gilda que se vista de homem para fugirem do reino. Enquanto isso, procura um assassino profissional para matar o Duque, pedindo para atirar o corpo ao Rio. Gilda, disfarçada de homem, segue o Duque até uma estalagem e lá também encontra o assassino que seu pai contratou. Gilda, desesperada, resolve sacrificar-se e, enganando o assassino, é apunhalada e morta. Rigoletto, ao pegar o corpo que está fechado no saco, ouve o Duque a cantar ao longe e descobre então que no saco está a sua filha em agonia. Gilda morre nos seus braços e a maldição de Rigoletto cumpre-se duplamente.

Gilda é uma jovem superprotegida pelo pai. Muito tímida, mas alegre, facilmente se apaixona e se deixa seduzir pelo "mulherengo" Duque de Mântua. Na ária "Tutte le feste al tempio", Gilda descreve ao seu pai o que aconteceu com ela no palácio. Conta-lhe como se apaixonou por um jovem estudante que, afinal, era o Duque disfarçado, como foi raptada por homens que desconhecia e como foi deflorada pelo Duque.

As emoções por ela expressas são: amor, medo, vergonha e desespero. Amor quando recorda como se apaixonou e como continua apaixonada; medo e desespero, pela lembrança do seu violento rapto, e vergonha, por ter sido seduzida pelo Duque, mas por quem continua apaixonada, sendo agora uma mulher desonrada, sujando o bom nome do seu pai e desiludindo o homem que sempre a protegeu.

$\mathrm{Na}$ ária "Tutte le feste al tempio", não encontramos grandes dificuldades, uma vez que é uma ária relativamente curta, as respirações estão bem marcadas e a tessitura, no geral, é bastante confortável, tendo em conta as caraterísticas da intérprete. A personagem inicialmente estava por detrás de um biombo, a simbolizar a vergonha sentida, pelo que não foi visível o seu rosto e a expressividade da expressão corporal passou para o espetador através do reflexo/transparência no biombo. Quando se deslocou para a boca de cena, direita alta, a emoção que mais transpareceu foi o medo/terror, que foi visível na expressão facial, com o rosto e os lábios em tensão, as sobrancelhas levantadas, os olhos bem abertos, o corpo rígido, mas algo fechado sobre si mesmo. Os braços também desempenharam um papel importante, com movimentações bruscas e repentinas, intensificando o grau do medo revelado.

\subsubsection{Oscar (Un Ballo in Maschera, 1859)}

Ária: "Volta la Terrea"

Libretista: Antonio Somma (1809-1864)) 
Compositor: Giuseppe Verdi (1813-1901)

Oscar é uma personagem masculina, um jovem adolescente. Verdi criou esta personagem para que fosse um elo de ligação com as outras personagens e para que tivesse uma aura de humor e, ao mesmo tempo, de crítica. No entanto, apesar de ser uma personagem masculina, Verdi compôs as árias desta personagem para uma voz de soprano, logo, para ser interpretada por uma mulher.

Oscar é um pajem do rei Gustavo III. Riccardo (Gustavo III) ama Amélia, a mulher do seu melhor amigo, Renato. Numa tentativa de erradicar esse amor proibido, Amélia consulta Ulrica, uma feiticeira, que lhe dá um feitiço para o efeito. Oscar, amigo de Ulrica, que é acusada de bruxaria, por um juiz, defende-a, descrevendo-a como uma pessoa popular e inofensiva. O rei, curioso, decide investigar por conta própria e, disfarçando-se de pescador, também consulta Ulrica, que prevê a sua morte. Renato descobre que Amélia e Riccardo se amam e depois de confrontar Amélia, jura vingar-se de Riccardo com a morte deste. Amélia, desesperada, envia uma mensagem, por Oscar, avisando Riccardo do perigo que corre. Durante um baile de máscaras, e depois de Renato obrigar Oscar a dizer-lhe qual o disfarce do rei, este é morto, apunhalado por Renato.

Oscar é um jovem insolente e corajoso, que realiza pequenas incumbências e leva mensagens ao Rei. Muito alegre e brincalhão, entra em todos os jogos, brincadeiras e mistérios que se lhe apresentam. Na ária "Volta la Terrea", o jovem pajem Oscar diz ao rei que a feiticeira Ulrica foi acusada de bruxaria e está prestes a ser proscrita. Um magistrado pede a sua expulsão, mas Oscar defende-a.

Oscar demonstra emoções como orgulho, interesse e esperança, por desejar que Ulrica não seja condenada, uma vez que acredita na sua inocência.

$\mathrm{Na}$ representação desta ária, a face da personagem estava coberta por uma máscara, apenas se vendo o lábio inferior, pelo que as emoções foram manifestadas pela expressão corporal e pela voz. A personagem movimentou-se como se tratasse de Arlequim da Commedia Dell'Arte, com as pernas arqueadas, os joelhos quebrados, as costas ligeiramente dobradas para trás e o peito para fora, as mãos fechadas sobre os quadris e os pés voltados para fora. Esta é uma ária com um andamento extremamente rápido, uma tessitura muito aguda e com staccatos constantes. Embora seja uma ária curta, é bastante difícil de executar.

\subsubsection{Anna (Le Villi, 1884)}


Ária: "Se come voi piccina io fossi"

Libretista: Ferdinando Fontana (1850-1919)

Compositor: Giacomo Puccini (1858-1924)

Roberto e Anna estão prestes a casar-se. A família e os convidados estão reunidos para celebrar o noivado dos dois. Roberto tem de sair antes da cerimónia do casamento para recolher uma herança. Embora feliz, Anna está preocupada e receosa em relação aos seus pressentimentos, pois sente que vai perder o seu amado, e pede a Roberto que nunca se esqueça dela e do amor dos dois. Mas o tempo passa e Roberto não volta. Anna descobre que ele se apaixonou por outra mulher e morre de desgosto. Transforma-se numa fada e junta-se às outras fadas para cumprirem o código que diz que quando uma mulher morre de coração partido, as fadas forçam o responsável a dançar até à morte. Roberto regressa depois de ser abandonado pela outra mulher e tenta reencontrar Anna. Quando sabe da sua morte arrepende-se de tê-la abandonado. No entanto, as fadas não o perdoam e Anna dança com Roberto até que este morre de exaustão aos seus pés.

Anna é uma jovem filha de boas famílias. Demonstra ser frágil e um pouco ingênua. A sua única preocupação é o seu amado. Na ária "Se come voi piccina io fossi”, Anna expressa as seguintes emoções: amor e felicidade - por estar noiva e se casar brevemente com o homem que ama - , ansiedade e medo pelo fato de ter o pressentimento (que se vai concretizar) de perder Roberto.

Nesta ária, a personagem, apesar de, momentaneamente, ter revelado um sorriso de felicidade, com os olhos sem brilho e os cantos dos lábios, ligeiramente, subidos, bem como as sobrancelhas, sem levantar as maçãs do rosto, demonstrou principalmente o seu receio e preocupação. Neste caso, as sobrancelhas estavam mais elevadas, os olhos mais semicerrados e distantes. As maçãs do rosto baixaram ligeiramente. A marcação cênica foi por estar de pé, sentada e novamente de pé. As dificuldades vocais mais relevantes foram algumas notas em pianíssimo e a existência de alguns ornamentos, como apogiaturas.

\subsubsection{Musetta (La Bohème, 1895)}

Ária: "Quando men vo"

Libretista: Giuseppe Giacosa (1847-1906) e Luigi Illica (1857-1919)

Jangada | nr. 14, jul/dez, 2019 | ISSN 2317-4722

72 |P á g in a 
Compositor: Giacomo Puccini (1858-1924)

A ação começa num pequeno, pobre e frio apartamento, no Quartier Latin, na região boêmia de Paris, onde dois artistas, o poeta Rodolfo e o pintor Marcello, trabalham na véspera do Natal. O filósofo Colline e o músico Schaunard vão visitá-los e levam vinho, mantimentos e charutos. Também oferecem bebidas ao proprietário, Benoit, que reclama pela renda atrasada. Uma vizinha bate à porta: é Mimi, uma jovem costureira. Logo que a vê Rodolfo apaixona-se, apesar da sua aparência doentia, convida-a a entrar e a sentar-se próxima do fogo. Mimi também se apaixona por Rodolfo.

Os jovens festejam a passagem de ano no terraço do café Momus. Chega Musetta, a examante de Marcello. Musetta é uma mulher muito sedutora e usa todo o seu charme para reconquistar Marcelo, que volta a cair nos seus braços. Mimi, tossindo intensamente, pede ajuda a Marcello, contando ao pintor que o seu relacionamento com Rodolfo está insuportável, por causa dos intensos ciúmes deste. Marcello promete-lhe que falará com Rodolfo. Este volta da taberna e Mimi esconde-se. O poeta conversa com Marcello e confessa-lhe que o ciúme é falso e que ainda a ama, mas como ela está muito doente e ele sente remorsos por mantê-la num lugar tão frio e pobre, onde a sua saúde pode piorar diariamente, fez de tudo para a afastar. Mimi, num acesso de tosse e soluços, denuncia a sua presença. Rodolfo tenta, em vão, convencê-la de que se irá curar, porém a jovem resolve separar-se dele. Musetta encontra Mimi na rua muito doente e conta aos rapazes o sucedido. Todos tentam socorrê-la, mas em vão. Mimi e Rodolfo relembram o passado e confessam o seu mútuo amor, mas Mimi morre nos braços do seu amado rodeada pelos seus amigos.

Musetta é uma mulher com uma personalidade e autoconfiança muito fortes. É sedutora, enérgica e sexy, e reage motivada pelo ciúme que tem pelo ex-namorado. Sem condicionantes sociais, faz o que bem entende. $\mathrm{Na}$ ária "Quando men vo", Musetta canta dirigindo-se a Marcello, que está fora de uma movimentada taberna. Ela o provoca e diz-lhe que este nunca a deveria ter deixado, uma vez que é tão bonita e sexy e que, na rua, o povo não consegue tirar os olhos dela. As emoções aqui expressas são: desejo e interesse por querer que Marcelo volte a cortejá-la; e alegria e prazer por ter um anseio imoderado de chamar atenção de todos os homens e mulheres sobre si.

Na representação desta ária, a personagem mostrou a sua alegria através da sua expressão corporal altiva e andar dançado, do seu olhar orgulhoso, com as sobrancelhas bem levantadas, olhares sedutores, olhos brilhantes, sorriso malicioso, com os cantos da boca elevados, bem Jangada | nr. 14, jul/dez, 2019 | ISSN 2317-4722 
como as maçãs do rosto, e os dentes visíveis. As dificuldades técnicas que se nos apresentaram foram o ter de quase dançar tango durante toda a ária, segurando um leque na mão direita, alternando com a esquerda, implicando bastante concentração, por forma a manter a colocação vocal.

\subsection{Encenação}

\subsubsection{As óperas e as personagens femininas}

As dez personagens selecionadas para este projeto, retiradas de dez óperas italianas do século XIX, representam um universo de estados emocionais diferentes e, concomitantemente, estes podem variar ao longo da mesma ária. Não obstante estarmos perante dez argumentos diferentes, precisávamos, para a encenação, de um fio condutor que pudesse interligar estas dez personagens (CABRAL, 2006). Não era nosso objetivo seguir a ordem cronológica, nem dos compositores, nem das apresentações públicas das óperas, nem da cronologia da época em que se passam os enredos, mas, antes, procurámos um fio condutor que pudesse, no seu conjunto, contar uma "nova" estória e harmonizar todo o espetáculo.

Começamos por observar as particularidades de cada uma das óperas que pudesse restringir essa disposição. Elaboramos, em seguida, uma lista de sínteses que sistematizasse os estados emocionais de cada uma:

Lucilla (La scala di seta, 1812): revela alegria e prazer por ser cortejada;

Anna (Maometto II 1820): manifesta sentimentos contraditórios, como tristeza e medo, por seu povo estar em guerra com o homem que ama e este poder morrer nessa batalha;

Norma (Norma, 1831): revela sentimentos como ansiedade, tristeza, medo e, por outro lado, a calma que tem de demonstrar perante o seu povo;

Elvira (I Puritani, 1835): exprime emoções contraditórias, como tristeza e desânimo, por pensar ter sido abandonada no altar, e, por outro lado, alegria exagerada, pedindo ao amado que volte para ela;

Marie (La Figlia del Reggimento, 1839): revela alegria, contentamento e orgulho, exaltando o seu regimento;

Rita (Rita, 1841): expressa alegria, interesse e prazer, por mandar no marido e ser a dona da estalagem;

Jangada | nr. 14, jul/dez, 2019 | ISSN 2317-4722 
Gilda (Rigoletto, 1850): manifesta sentimentos de medo, vergonha e amor, por ter sido raptada e se deixar seduzir pelo duque, que ainda ama;

Oscar (Un Ballo in Maschera, 1859): exprime orgulho, interesse e esperança, pois defende uma feiticeira perante o rei;

Anna (Le Villi, 1884): revela alegria, por estar noiva, e receio de perder o homem que ama;

Musetta (La Bohéme, 1895): expressa alegria e prazer, por se achar muito bonita, e desejo e interesse, por aspirar que o ex-namorado volte para ela.

Outro aspeto que nos pareceu importante para a encenação foi estudar as afinidades que pareciam existir entre as personalidades das personagens (VIANA, 2018b). Aí, procuramos encontrar um elo que nos permitisse estabelecer uma tabela condizente com o nosso propósito. Decompusemo-la em cinco grandes itens, unindo duas a duas as dez personagens. E estabelecemos, por fim, para esta unidade, cinco substantivos que identificam a relação de cada dupla de mulheres, a saber:

Rita

Musetta

Lucilla

Anna (Le Villi)

Norma

Anna (Maometto II)

Marie

Oscar

Gilda

Elvira
Viço / Energia

Ingenuidade

Altruísmo

Cooperação 
As cinco unidades encontradas, às quais, para um mais fácil entendimento, nos referiremos com o neologismo inidades ${ }^{5}$ - viço/energia, ingenuidade, altruísmo, cooperação e desilusão -, que serviram para criar uma relação entre as duplas de personagens femininas, aqui levantadas.

Definimos para a primeira dupla, o substantivo viço, como qualificativo das caraterísticas de ambas as personagens: Rita tem atitudes e comportamentos tradicionalmente atribuídos ao homem; e Musetta apresenta publicamente uma vaidade e frescura pouco comuns numa senhora da época. A segunda inidade classificamo-la de ingenuidade, aqui o caso típico da donzela apaixonada, para a Lucilla e Anna (Le Villi). O altruísmo dedicamo-lo às personagens Norma e Anna (Maometto II), pela sua entrega à causa comum. À quarta dupla atribuímos a cooperação, pelo seu papel de coadjuvação na história: Marie foi criada desde pequena no seio do exército, sentindo-se como mais um elemento; e Oscar é um pajem que vai interceder a favor de Ulrica para que esta não seja expatriada. Por fim, para Gilda e Elvira atribuímos a designação de desilusão, a primeira por ter sido raptada e desflorada e a segunda por sentir-se rejeitada pelo noivo no altar.

Estabelecidas estas cinco inidades, o número cinco foi imageticamente demarcado como simbólico de todo o espetáculo. Esta cifra estará, portanto, presente na estrutura, na iluminação, bem como nos elementos cênicos deste projeto.

Seguidamente, analisamos o tempo e o espaço em que cada ação tinha lugar. Apesar de os tempos e os espaços de cada ação serem diferentes, pareceu-nos interessante reunir no mesmo espaço cênico cada dupla, mantendo a sua unidade, definida, como dissemos, pelos cinco substantivos. Contudo, essas duplas não foram inscritas pela ordem de apresentação do espetáculo que começa, por exemplo, pela personagem Rita da ópera "Rita" de Donizetti, e é sucedida de Lucilla de "La scala di seta" de Rossini.

Com efeito, na ordem de entrada das personagens, tivemos em consideração não só a progressão temática entre as cinco inidades, alternando-as entre si, por forma a não tornar o espetáculo demasiado homogêneo (e eventualmente monótono) e as diferenças entre os estados emocionais das personagens fossem claramente detectadas pelo público. Também tivemos em consideração o esforço vocal exigido à intérprete, intercalando entre árias vocalmente mais exigentes, com coloratura e notas mais agudas por exemplo, e outras vocalmente menos

\footnotetext{
${ }^{5}$ Termo criado a partir da abreviatura de feminidade (com eliminação do radical da palavra), por analogia com o substantivo "unidade".
}

Jangada | nr. 14, jul/dez, 2019 | ISSN 2317-4722 
exigentes. Por isso, determinámos, no palco, o espaço para cada uma das inidades e estas, ainda que tivessem demarcados os seus lugares em cena, não ficaram cingidas a uma área restrita, podendo, obviamente, percorrer todo o palco, inclusive a plateia.

Assim, o resultado final da ordem de apresentação das dez personagens no espetáculo foi a seguinte:

1- Rita: "E` lindo e civettin questo caro alberguccio" - Donizetti, de Rita (1841)

2- Lucilla: "Sento talor nell'anima" - Rossini, de La scala di seta (1812)

3- Anna 1": "Se come voi piccina io fossi" - Puccini, de Le Villi (1884)

4- Norma: "Casta Diva" - Bellini, de Norma (1831)

5- Marie: "Ciascun lo dice" - Donizetti, de La Figlia del Reggimento (1839)

\section{Intervalo}

6- Oscar: "Volta la Terrea..." - Verdi, de Un Ballo in Maschera (1859)

7- Musetta: "Quando m’en vo" - Puccini, de La Bohéme (1895)

8- Anna 2*: "Gusto Ciel. in tal periglio" - Rossini, de Maometto II (1820)

9- Gilda: "Tutte le feste al tempio" - Verdi, de Rigoletto (1850)

10- Elvira: "Qui la voce sua soave... bien diletto" - Bellini, de I Puritani (1835)

\subsubsection{Os adereços}

No levantamento dos objetos de cena, não há uma listagem com adereços específicos para todas as personagens, havendo mulheres e inidades sem qualquer elemento cênico. Esta opção deveuse ao fato de, quando em palco existirem demasiados elementos, usados pelas personagens, estes podem tornar-se, para o espetador, "lixo visual", uma vez que a atenção do espetador pode focar-se nos elementos cenográficos e não diretamente no trabalho do ator. Deste modo, entendemos que os adereços que selecionamos enriqueceram essas personagens e a interpretação da ária.

\footnotetext{
* Para distinguir as personagens Anna de Le Villi e Anna de Maometto II, utilizámos a ordem do espetáculo para lhes atribuir os números $1 \mathrm{e} 2$, respetivamente.
}

Jangada | nr. 14, jul/dez, 2019 | ISSN 2317-4722 
O resultado final desta catalogação correspondeu, em termos de ornamentos a: lanterna, cornetim, leque, lenço branco e cabeças de cera, que correspondem ao mesmo número de inidades, isto é, a cifra 5.

Com efeito, apresenta-se a lista com os adereços para as dez personagens, pela ordem das cinco inidades:

- Rita - 1 lanterna;

- Musetta - 1 leque vermelho;

- Lucilla - 1 lenço branco;

- Anna $1-$

- Norma -

- Anna $2-$

- Marie - 1 cornetim;

- Oscar - [máscara $]^{6}$

- Gilda -

- Elvira - Bandeja com 5 cabeças de cera.

Rita aparece em cena com uma lanterna, entrando pela plateia. A casa, em que vai entrar, estava fechada à espera dela, logo está às escuras, sem luz, sem vida, o que leva a que Rita traga a lanterna para iluminar a sua nova casa.

Musetta abana um leque de cor vermelha. Esta personagem tem uma carga de frescura, que nos levou ao substantivo viço (como para Rita) para a inidade onde a incluímos. Esse viço, por outras palavras, o fervor sexual dela, exige que ela alivie esse calor, abanando um leque pintado de uma cor quente e chamativa, o vermelho.

Lucilla, ao segurar um lenço branco, simboliza a sua inocência e ingenuidade, mas a movimentação feita com o mesmo denota a sua excitação por ser cortejada por um homem, tendo em vista um possível casamento.

\footnotetext{
${ }^{6}$ Máscara: s.f. artefacto de cartão, pano, cera e/ou outros materiais, que representa uma cara ou parte dela, e destinado a cobrir o rosto para disfarçar a pessoa que o põe (Costa et al. 2005: 1084); "Máscara é o que transforma, simula, oculta e revela. Se bonecos, imagens e marionetes representam o homem, a máscara é sua metamorfose. Por sua rigidez, prende o momento, registra e fixa o essencial, mais permanente. O rosto humano está sujeito a instabilidades emocionais, reflete o interior da alma e facilmente se deixa trair. Já a máscara é como um rosto sem interior. Ao vesti-la, o ator assume sua parte racional e sensitiva, assim como constrói o seu corpo." (Amaral 2002: 41).
}

Jangada | nr. 14, jul/dez, 2019 | ISSN 2317-4722 
Marie é apresentada como "filha do regimento", uma rapariga que fora criada no seio dessa instituição. Está habituada a todos os trâmites da vida militar, o que a leva a ser, à sua maneira, de certo modo, um pouco masculina. A ária interpretada começa por uma espécie de chamamento, como se de um toque de alvorada se tratasse. Este fato levou-nos à escolha de um cornetim para Marie.

A personagem Oscar usa uma máscara, que não consideramos propriamente como um adereço, mas uma extensão do corpo do ator (para a criação da personagem), tendo-a, por isso, colocado entre parêntesis retos (Luís de Matos,2008).

Oscar, embora seja interpretado por uma mulher, é, na estória, um pajem que, na nossa versão usa uma máscara de Arlequim, fazendo assim ligação àquele criado da Commedia Dell'Arte.

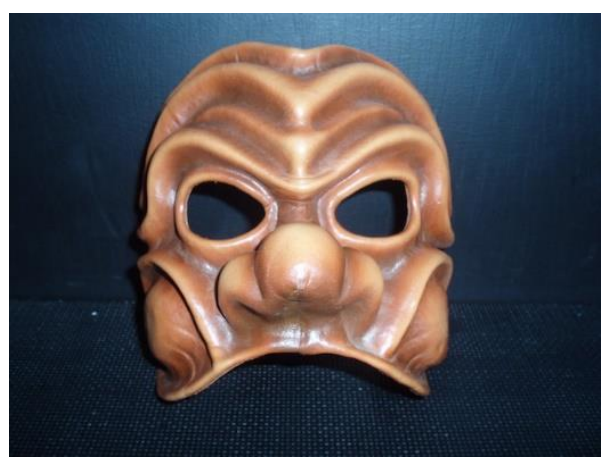

Fig. 1 Máscara

Elvira traz 5 cabeças de cera, as quais, em termos religiosos, são símbolo de devoção para promessas ligadas às doenças da cabeça. Elvira enlouquece no final, também ela vai sofrer de uma "doença da cabeça", transportando consigo esses cinco objetos de cera, sobre uma bandeja, numa alusão à cabeça de São João Batista, servida sobre a bandeja a Herodes, a pedido de Salomé7.

\footnotetext{
${ }^{7}$ A analogia da loucura de Salomé com a de Elvira serviu unicamente de fonte de inspiração para o trabalho de encenação, que veio completar a simbologia desta última personagem e do todo do espetáculo.
} 


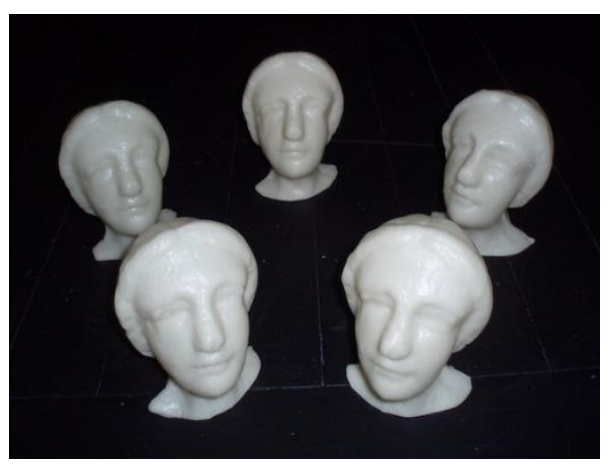

Fig. 2 Cabeças de Cera

\subsubsection{As inidades e a unidade no todo do espetáculo}

Pedro Barbosa (2003, p. 79) apresentou um esquema a que chamou «polígono teatral», em que envolve todos os intervenientes cênicos como essenciais processo de criação teatral, iniciandose no dramaturgo, bifurcando-se no encenador e atores, com os técnicos no centro e terminando no público, da seguinte forma:

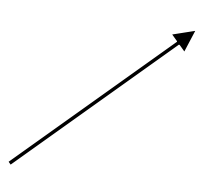

Dramaturgo

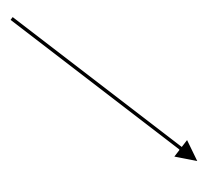

Encenador

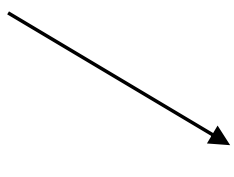

Técnicos

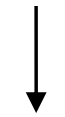

Atores
Público

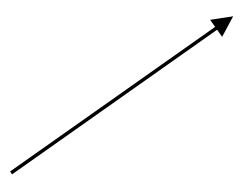

No que concerne a esta relação entre todos os elementos que compõem o espetáculo, Barbosa (2003, p. 80) acrescenta que a relação ator-público é absolutamente fundamental numa produção artística teatral, que não existe em outras artes de expressão dramática, como o cinema, por exemplo:

O teatro só existe pela presença simultânea do ator e do espectador. A isso, em última instância, ele se resume. A simples presença de uns quantos actores em cima do palco, olhando demoradamente um público em silêncio, pode 
produzir um efeito dramático da maior intensidade: só pelo simples poder da presença imediata (...) o essencial, no teatro, é a presença do homem vivo, do ator em carne e osso, manifestando-se no aqui-e-agora que é o espetáculo (...) e faz do teatro um encontro recíproco de pessoas vivas: um corpo-a-corpo entre actores e espectadores.

Para encenar este projeto e criar uma unidade do espetáculo, concebemos, em termos imagéticos, uma estrutura dramática do espetáculo, com a alusão aos cinco elementos elencados por Barbosa, com base em cinco inidades, que podemos sistematizar da seguinte forma:

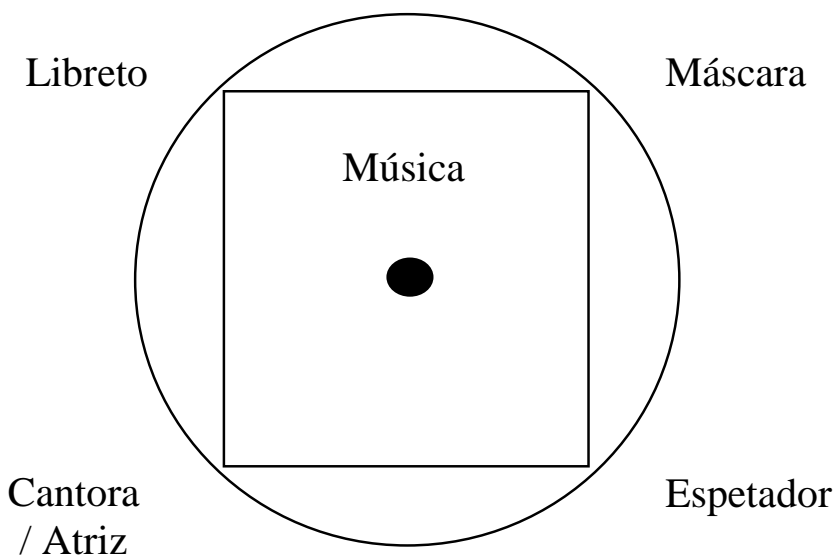

Para a elaboração e distribuição destes cinco elementos ou inidades, definimos uma sequência condizente com a criação de um espetáculo operístico, que se deve caracterizar, em nossa opinião, no início deste século $\mathrm{XXI}^{8}$, por uma maior essência teatral, no sentido de que o que verdadeiramente é importante é o trabalho do ator-cantor e a sua relação com o público, defendida por Barbosa. A verdade que passa para o espectador e a história que se quer contar é, no fundo, tanto mais verosímil quanto mais apurado é o trabalho do ator-cantor, onde a inquietação maior está no conteúdo da mensagem, na essência da melodia e sua interpretação.

\footnotetext{
${ }^{8}$ Até finais do século passado, um espetáculo operístico tinha mais em consideração o efeito visual, preocupandose com a beleza e com a grandiosidade cênica, com a sonoplastia, o figurino, onde, justamente a mistura desses elementos acabava deslumbrando o espectador, até mesmo em detrimento do texto e das atuações. O cantor era apenas cantor e o seu trabalho de ator era deixado para último plano, pois o que deveria ser levado em conta era a sua virtuosidade vocal, em prejuízo da interpretação.
} 
Assim, em primeiro lugar surge o libreto. O libreto irá dar o mote para a composição musical, a qual colocamos no centro da imagem, inserida num círculo (de energia) como eixo de toda a obra. Em seguida no canto inferior esquerdo inscreve-se a cantora/atriz, cuja linha de vértice a vértice se vai encontrar com a máscara (persona = máscara) em cima à direita. $\mathrm{E}$ por fim no canto inferior direito, temos o espetador.

O desenho representa a caixa de palco, sendo que junto ao proscênio se encontra a cantora/atriz e o espetador, e os restantes componentes do espetáculo são distribuídos pelo resto do tablado. Esta figura poderá parecer um desenho de marcações para a cantora/atriz, limitando o seu espaço de ação à EB (esquerda baixa). Mas não, o quadro é tão-somente a estruturação simbólica dos cinco elementos definidos para a encenação.

A música é inscrita no centro, do qual se expande a primeira energia, cuja "explosão" a partir do núcleo irrompe para todos os lados, passando por todos os vértices. Destes últimos, aquela energia primordial, recebe de todas as frentes uma segunda força, que advém dos outros quatro membros integrantes do espetáculo, cantora/atriz, máscara, libreto e espetador, retornando com maior força ao ponto de partida, ao centro, numa simbiose perfeita entre todos. A energia despendida pela cantora irá chegar ao espetador, que se transformará em emoção, havendo deste uma presença e entrega sentidas do outro lado pela executante, e vice-versa. A interação será, pois, uma constante.

Por outro lado, a encenação contemporânea tem privilegiado o trinômio cênico baseado nos termos tempo, espaço e ação. Para percebermos a estrutura do espaço, recorremos a uma explicação de Pavis (2005, p. 132) que expõe esse componente da encenação teatral e do texto dramático de modo didático, a explicar as diferenças básicas entre espaço dramático e espaço cênico. O primeiro “(...) é o espaço dramatúrgico do qual o texto fala, espaço abstrato e que o leitor ou o espectador deve construir pela imaginação (ficcionalizando).” Já o segundo “(...) é o espaço real do palco onde evoluem os atores, quer eles se restrinjam ao espaço propriamente dito da área cênica, quer evoluam no meio do público.” (PAVIS, 2005, p. 132). Relacionando os espaços em questão, Pavis defende que

Espaço dramático opõe-se a espaço cênico (ou espaço teatral). Este último é visível e se concretiza na encenação. O primeiro é um espaço construído pelo espectador ou pelo leitor para fixar o âmbito da evolução da ação e das personagens; pertence ao texto dramático e só é visualizado quando o espectador constrói imaginariamente o espaço dramático. (2005, p. 135) 
O espaço dramático pode transpor as construções cenográficas ou as indicações cênicas que levam o espetador a espaço particular. Não se trata apenas do cenário elaborado para uma determinada cena, ou do espaço sugerido pelas didascálias, mas tal espaço deve ser sugerido, em pequena escala, pelas didascálias e pela cenografia, mas não deixa de ser um elemento mais complexo na encenação teatral.

Por seu turno, o tempo é “(...) um dos elementos fundamentais do texto dramático e/ou da manifestação cênica da obra teatral, de sua representação (presentificação cênica)." (PAVIS, 2005, p. 400) Este autor trata do tempo de forma extensa, e o seu estudo parte de dois tipos de tempo: o tempo cênico e o tempo dramático. O tempo cênico é

(...) aquele da representação que está se desenrolando e aquele do espectador que está assistindo. Consiste num presente contínuo, que não para de desvanecer-se, renovando-se sem cessar. Essa temporalidade é ao mesmo tempo cronologicamente mensurável (...) e psicologicamente ligada ao sentido subjetivo da duração do espectador. (PAVIS, 2005, p. 400)

Não se trata do tempo de duração da peça, este ponto cabe ao tempo cênico, mas antes da articulação de unidade de tempo dentro da história.

O tempo dramático (PAVIS, 2005, p. 401) pode ser ratificado no estudo do texto escrito para o teatro, pois podem ser explicitadas as valências necessárias para a apreensão da escolha, disposição e organização do tempo. Já o tempo cênico deve ser observado na representação, uma vez que se trata de comensurá-lo em tempo contínuo durante a encenação teatral.

No que concerne à ação/ritmo, Pavis (2005, p. 139) defende que o estudo deste elemento ultrapassa o campo do teatro e da literatura, fundamentando-se em bases fisiológicas, como a respiração ou o batimento cardíaco. $\mathrm{O}$ autor apresenta extensas concepções, principalmente sobre o ritmo da encenação, uma vez que este é de fundamental importância tanto para o trabalho vocal e gestual, como para o desenrolar do espetáculo.

É a ação que dá vida às partes do discurso. É o ritmo que dá expressão aos conflitos, que dá a divisão dos tempos fortes e fracos, que dá a aceleração ou a diminuição das interações. É o ritmo/ação que impõe uma operação dramatúrgica no conjunto da representação.

Baseada no trinômio cênico de Pavis, esta proposta de encenação, poderia ser representada do seguinte modo: 
Tempo

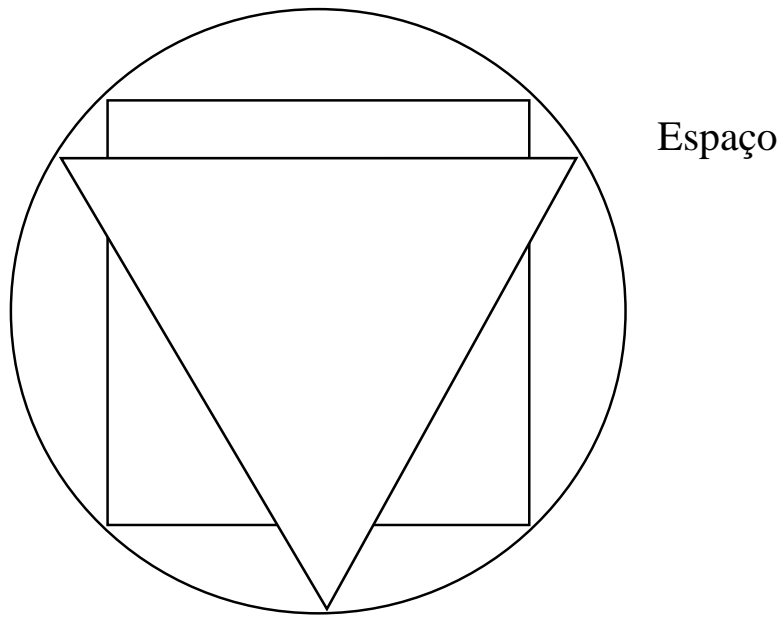

Ação

O triângulo equilátero integrado na figura do quadrado e do círculo compõem o conjunto que representa todo o espetáculo. O desenho do triângulo invertido serve os propósitos de enquadramento de todos os membros integrantes e o seu lugar no espetáculo. Do mesmo modo que a atriz fica na EB (esquerda baixa), a ação assume a sua posição fronteira no CB (centro baixo).

\subsubsection{Os elementos cenográficos}

Com base nas cinco inidades encontradas, dedicamo-nos à cenografia, neste caso concreto, aos elementos cenográficos, que estabelecessem o elo entre todas as árias e servissem o todo da encenação. Reunimos os objetos seguintes:

- 25 Velas;

- 25 Suportes de vidro para as velas.

- 5 lençóis;

- 1 biombo;

- 1 espelho (sobre um cavalete de pintura);

- 1 jarrão ${ }^{9}$;

\footnotetext{
${ }^{9}$ Este objeto irá fazer parte da caixa "matrioska".
} 
- 1 caixa redonda "matrioska"10

Como vimos, no período romântico, o papel da mulher relegava-se para um segundo plano em relação ao homem, tendo ela de resguardar-se, numa sujeição constante à figura masculina. Devia manter-se em casa, à espera de sair dali, para entrar noutra casa, depois de um contrato de casamento celebrado entre famílias.

Quisemos, no entanto, em termos imagéticos, ir ao encontro da época em que os libretos se escreveram, portanto, o século XIX. Recorremos hoje à eletricidade para os jogos de luz nas artes do espetáculo, em oposição às óperas do oitocentos que, quando estrearam, faziam-se iluminar por velas. Mantivemos estas, indo, no entanto, para o nosso jogo cênico, em direção a uma simbologia encontrada nas inidades, ou seja, o número 5. Iluminamos, então, a cena com 5 múltiplos de 5, o que perfaz 25 velas, 20 destas colocadas sobre outros tantos suportes de vidro, criando, assim, uma ribalta. Os suportes de vidro, para além de protegerem o palco da cera, funcionam igualmente - por serem de vidro - como refletores.

As restantes 5 velas ficam ao lado do piano, dando luz à pianista e complementando a iluminação cénica. Estas cinco velas, ainda que fazendo parte dos 5 múltiplos de 5, têm o dobro da altura das outras 20, em primeiro lugar por iluminarem o piano (o elemento cenográfico mais imponente em cena) e, em segundo, por este encerrar em si o centro nevrálgico, a música e, por inerência, a voz da cantora/atriz. Mesmo que as velas da ribalta se consumissem durante a atuação, as cinco do piano permaneceriam, como o murmúrio da cantora/atriz que se entranhou na sala e nos espetadores, ficando a ecoar para além do fim do espetáculo.

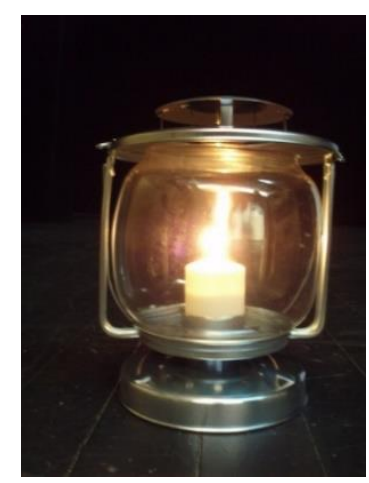

Fig. 3 lanterna

\footnotetext{
${ }^{10}$ A caixa manipulada por Gilda, a que chamámos "matrioska", que, aberta, se decompõe em quatro, juntando-selhe o jarrão, com que perfaz o número 5, é uma caixa redonda para guardar chapéus (outro elemento da mulher aristocrata oitocentista), que encaixam umas nas outras como as tradicionais bonecas russas.
} 
As várias casas das personagens transformaram-se para nós na "casa”, a nossa casa, isto é, o palco. Rita, a primeira personagem a entrar em cena, vem acompanhada de uma lanterna, surgindo da plateia, chegando à nova casa do segundo marido. Esta casa estava, na nossa versão, à espera de vida feminina, por isso, todas as mobílias estão ao início cobertas por lençóis, que as protegem do pó.

O biombo preto, de linhas direitas e quadrados brancos translúcidos, é usado na cena para ocultação de objetos e da própria cantora/atriz, servindo depois para provocar outras imagens em sombra.

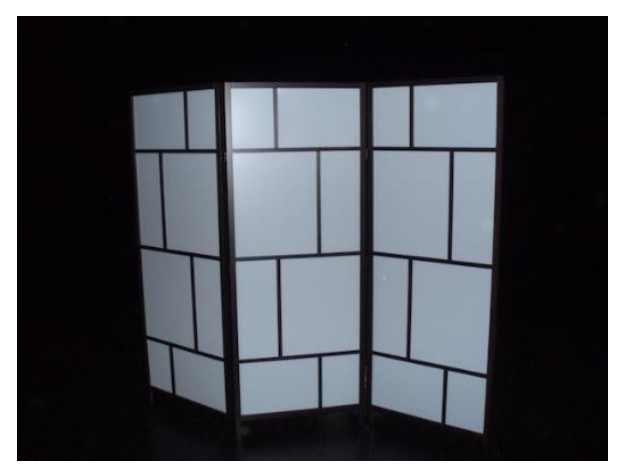

Fig. 4 Biombo

O espelho é, por inerência, associado à mulher, símbolo de vaidade feminina. A imagem da Mulher colocamo-la (uma vez mais em termos simbólicos) sobre o cavalete de pintura, assumindo a reprodução de um retrato pintado. Esta mulher usa o espelho para ver-se e ser vista tal como ela é. Este espelho é, pois, o "retrato" da Mulher.

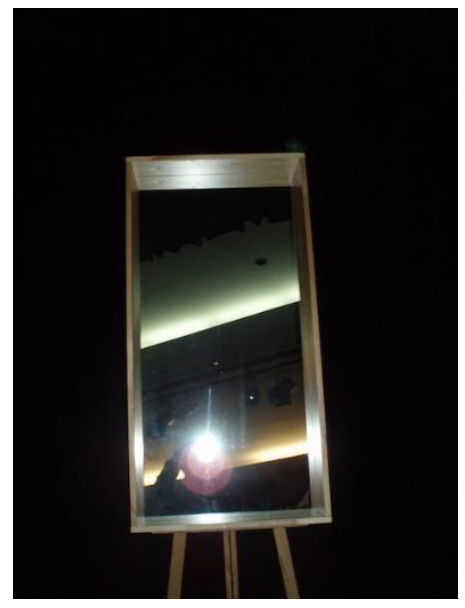

Fig. 5 Espelho 
O jarrão em forma de cone invertido, de cor preta de meio para cima e creme de meio para baixo (a condizer com a cor das velas), faz o complemento com as caixas "matrioskas", perfazendo a cifra 5. Este vaso liga o preto à cor negra do piano e do biombo, enquanto o creme faz a ligação ao cavalete, à moldura do espelho e às velas.

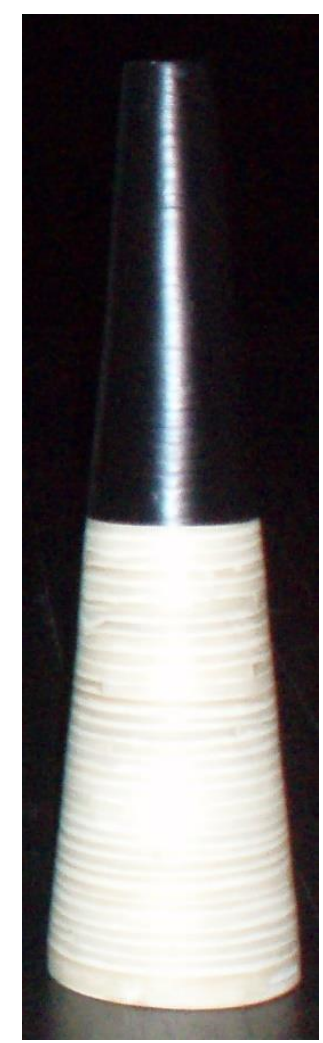

Fig. 6 Jarrão

A caixa "matrioska", preta, que, aberta, se decompõe em quatro, fazendo um complemento com o jarrão. Simboliza a perda da virgindade de Gilda, aberta, à semelhança da caixa de Pandora, de onde se evadem os vários mistérios. Ela era uma rapariga ainda donzela, que viu o seu bem mais precioso, segundo os cânones da época, "roubado" e, por isso, exposto...

O número 5, encontrado nas cinco inidades, percorre, como vimos, todo o espetáculo, não podendo, igualmente, faltar na cenografia. Os elementos cenográficos teriam de ser também eles cinco. Assim: o piano (1), o biombo (2), o espelho no cavalete (3), o jarrão (4) e as caixas (5), os quais identificamos na figura abaixo. 
Observe-se, ainda, na imagem, a ribalta, constituída pelas 20 velas e as outras 5 colocadas ao lado do piano. Deixamos fora da planta de cena (stage plot) os cinco lençóis que ocultariam os elementos cenográficos, ou seja, por cima da pianista, do piano, sobre o biombo, o espelho e a cobrir o jarrão.

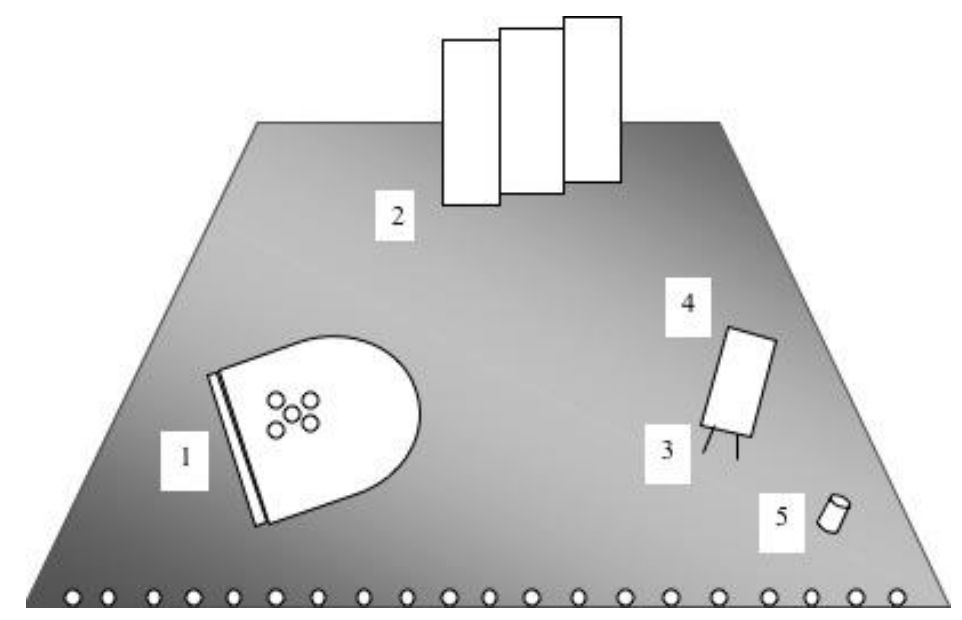

Fig. 7 Planta de Cena

\section{Conclusão}

Este artigo resulta de um trabalho de pesquisa de um quadro de referência teórico, que levou ao desenvolvimento de um projeto artístico, com a encenação e interpretação de dez árias de dez personagens (e óperas) diferentes de cinco compositores italianos do século XIX. Discutiu-se a construção da personagem no teatro e, particularmente, na ópera, onde a fundamentação teórica foi fundamental para a realização do projeto artístico, facultando um enriquecimento global e permitindo-lhe acrescentar uma base científica ao trabalho, que consistiu na encenação de um espetáculo, composto por duas árias de cada um dos cinco compositores italianos já referidos, com cerca de 45 minutos. Não era intenção apresentá-las por ordem cronológica, mas, antes, encontrar um fio condutor que pudesse interligá-las e criar um espetáculo homogêneo, como se se estivesse a contar uma "única" história. Para isso, começou-se por analisar cada uma das personagens, procurando uma síntese dos estados emocionais de cada uma. Elaborou-se uma síntese para cada uma, o que resultou no elo que se decompôs em cinco itens, unindo as personagens duas as duas, com um substantivo para cada par. Essas caraterísticas foram designadas com o neologismo inidades, criado, por analogia com o termo unidade, a partir da abreviatura do substantivo feminidade. 


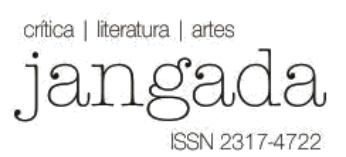

Por último, estabeleceu-se a ordem de entrada das personagens em palco, tendo, como critérios fundamentais, a progressão temática entre as inidades, com alguma alternância, por forma a não tornar o espetáculo demasiado monótono, mas que as diferenças entre os estados emocionais das personagens se mantivessem claramente observáveis pelo público. Também se usou o critério do esforço vocal exigido, alternando árias vocalmente mais ou menos exigentes.

Por fim, realizou-se a encenação propriamente dita, com a escolha dos adereços tendo em conta as inidades, os objetos em cena, a iluminação, as marcações de cada uma das personagens, e outros elementos cenográficos, que pudessem estabelecer elos de ligação entre todas as árias e servissem o conjunto.

Através do trabalho desenvolvido neste projeto, chegamos à conclusão de que não é possível realizar uma correta interpretação de uma ária sob o ponto de vista dramático, ainda que vocal e tecnicamente bem executada, sem conhecer previamente a personagem, a sua personalidade e, especialmente, os estados emocionais presentes em cada um dos momentos. Estes podem ser simples, mas são, na maior parte das vezes, complexos e difíceis de interpretar do ponto de vista emocional. Atingir uma interpretação coerente e convincente, não só do ponto de vista estritamente musical, mas essencialmente do ponto de vista da veracidade das emoções, só é possível com uma grande preparação do ator-cantor, com técnicas performativas exigentes, que lhe permitam fazer chegar ao espectador essa veracidade emotiva da personagem.

\section{REFERÊNCIAS BIBLIOGRÁFICAS}

AMARAL, Ana Maria. O ator e seus duplos: máscaras, bonecos, objetos. São Paulo: Editora SENAC, 2002.

ARAÚJO, José Manuel da Silva. Canto e Emoção - indicadores emocionais não verbais na execução do discurso musical cantado. Tese de Doutoramento. Aveiro. Universidade de Aveiro, 2012.

BARBOSA, Pedro. Teoria do Teatro Moderno: A hora zero. Porto: Edições Afrontamento, 2003.

CABRAL, Carlos. Manual de Encenação. Lisboa: INATEL, 2006.

COSTA, J. Almeida \& MELO, A. Sampaio. Dicionário da Língua Portuguesa. Porto: Porto Editora, 2005.

MATOS, Luís de. Manual de Objectos de Cena. Lisboa: INATEL, 2008.

MAYS, Desirée. Opera unveiled 2012. Opera Unveiled Series, vol. 14. Santa Fe: Santa Fe Opera, 2012.

PAVIS, Patrice. Dicionário de Teatro. São Paulo: Editora Perspectiva, 2005. 
SIMÕES, Edson (2010): “A construção da personagem no teatro pelo olhar da psicologia social". Encontro: Revista de Psicologia, vol. 13, n.o 19, p. 33-53.

THAMM, Robert A. "The Classification of Emotions". In: STETS, Jan E. \& Jonathan H. TURNER (eds). Handbook of the Sociology of Emotions. New York: Springer, p. 11-37, 2006. VIANA, Isabel. A Personagem Feminina em Óperas do Romantismo Italiano: estados emocionais em dez árias para soprano. Dissertação de Mestrado. Aveiro: Universidade de Aveiro, 2012.

VIANA, Isabel. "Comunicação não verbal e expressões faciais das emoções básicas". In: Revista de Letras, 13, p. 165-181, 2014.

VIANA, Isabel. "O papel da mulher na ópera italiana do século XIX”. In: Jangada: crítica, literatura, artes, 12 (Vozes d'Além-Mar / Voices Beyond the Sea), p. 138-157, 2018a.

VIANA, Isabel. "Métodos de Construção da Personagem nas Artes Performativas". In: SOARES, Maria Luísa, Natália AMARANTE, Daniela FONSECA, Sónia COELHO \& Susana FONTES (eds). (Co)Insistências: Estudos em Letras, Artes e Comunicação. Vila Real: Centro de Estudos em Letras, p. 121-132, 2018 b. 